\title{
Factors Influencing Strategic Information Systems Implementation In Government Parastatals: A Case Of Kenya Forest Service, Mau Forest Conservancy
}

\author{
Dorothy C. Koech \\ Kenya Methodist University, Eldoret,Kenya \\ Dr. Evangeline M. Gichunge \\ Ann Thuo \\ Kenya Methodist University, Nairobi,Kenya
}

doi: 10.19044/esj.2016.v12n15p263 URL:http://dx.doi.org/10.19044/esj.2016.v12n15p263

\begin{abstract}
The operations of parastatals could be greatly enhanced by the wellfocused application of information systems to support improvements in productivity, management effectiveness and ultimately, the quality of services offered to citizens. Assessing the strategies of information systems (ISs) implementation has been identified as one of the most critical issues in IS field. However, studies relating to this issue within the context of kenyan parastatals are few and lack the ability to propose a major set of factors influencing the strategic IS implementation. The study sought to determine the influence of top management support, expertise, infrastructure and enduser training on strategic information systems implementation at Kenya Forest Service. The study adopted descriptive research design using a sample of 262 drawn from a population of 831 staff of the Kenya Forest Service, Head of Conservancy Mau selected using stratified and simple random sampling technique. Data was collected by questionnaires and analysed by descriptive statistics and multiple regression analysis. The findings revealed that the relationship of top management support, expertise, end-user training and infrastructure explain a strong change in strategic information systems implementation. The study concluded that to ensure strategy is implemented as intended, senior executives must endevour to persuade the employees of their ideas and that IT professionals' technical backgrounds is critical both during the selection and acquisition of complex IT system and for the implementation of information system into adopting organizations.
\end{abstract}

Keywords: Strategic information systems, parastatals, Kenya 


\section{Introduction}

During the growth of a competitive global environment, there is considerable pressure on most organizations to make their operational, tactical, and strategic processes more efficient and effective. Parastatals are formed to provide services that are generally in public interest that private sector may not provide on grounds of heavy capital investment needed at initial stages. (Wordnik, 2015). In today's fast paced and increasingly complex world information systems has become inevitable. To adjust accordingly, organizations have become more technology driven than ever before and the public sector is not being left behind. This requires organizations to be open and willing to change and once an organization decides to undergo such a radical change, considerable effort is required to manage it. Computer based information systems have reduced transaction costs, altered nature of operations in organizations, enabled firms to develop closer relationships with their clients and created new opportunities for organizations (Bellamy \& Taylor 1998, Bekkers \& Zouridis 1999).

Recent generations of information systems in public sector support electronic delivery of public services to the citizens and business enterprises by enabling them to make most of their transactions with the government through electronic channels such as the Internet (Bellamy \& Taylor 1998, Bekkers \& Zouridis 1999). Despite the proliferation of computer based applications in public sector, the implementation of systems remains a significant issue. Implementation of projects needs involvement of senior executive to ensure that the right participation mix of Business and IT is done and to resolve conflicts (Turbit, 2005).Burke et al (2001) identified poor skill sets among users as an issue. Furthermore, in the same study, 66\% of organizations identified lack of executive awareness as having a similar affect.

A case study based on Mascot Truck Parts cited in Maguire (2002) revealed that they had problems implementing a new IS because they did not have enough experience with regards to the processes involved and incidentally the system was not setup properly. In any business the use of personnel with expertise enhances the ability of a parastatal to be successful in implementing large, complex, or difficult tasks. It allows for both deeper and stronger skills and the contribution of differing perspectives. The effort to build interfaces, change reports, customize software and convert data is normally underestimated. To collect new data and clean the data being converted will also require an effort that is beyond what is normally expected (Turbit, 2005). Gutpa (2000) states that, many common problems with regards to ISs implementation are based around networking issues. These can include problems such as configuring the entire PC's to use the new information system and exchange information. Slow network infrastructure 
and low band width sometimes pose challenge in the implementation of system as the system operates slowly thus, limiting expected benefit of quick transaction processing.

Parastatals are constantly bombarded with many ongoing internal and external pressures that influence the necessity for information system implementation. The organization, therefore, must either take on the strategies of implementing new ISs or accept whatever the consequences that may be limiting ISs development. Whereas businesses sector must continuously grow organically to survive, parastatals must constantly adapt to the changes in the marketplace and diversify to meet the changing global demands. Organizations are generally afraid of IS project failure because they make big investments to a project in terms of money, time and man power. More than 70 per cent of standard package implementation projects fail (Milis \& Mercken, 2002). Therefore, IS implementation is surrounded with various problems regarding the implementation process and it is not easy to succeed. With the development of ISs there is always the hope for seamless ISs implementation and the citizens expects that there will be no interruptions of government services. However, there are many opportunities for things to go wrong during ISs implementation and parastatals take a number of risks when embarking on this course of action (Maguire, 2002). Organizations often fail to determine the factors that influence the success of the project at the very beginning. Therefore awareness of the factors that influence strategic information systems implementation will be very useful for this process.

In Kenya studies done on strategy implementation include Waema (2009), he studied the implementation of the financial management system in local authorities. Nyamboga and Gongera (2014) on the other hand did an evaluation of strategy implementation on organization effectiveness. Magutu and Lelei (2010) examined information systems implementation in state corporations, a critical evaluation of the process and challenges in Kenyan parastatals. While such research is useful in providing insight about ISs implementation, it provides little guidance on the factors that influence strategic information systems implementation. However, in the studies done in Kenya no attention has particularly been made on the factors influencing strategic information systems implementation in parastatals, hence there is need to analyze these factors. These studies focused on a different context and concept from what the current study seeks to cover. Given the importance of these strategies, this study therefore attempts to categorize the strategic influence of the factors including top management support, expertise, end-user training and infrastructure in ISs implementation, whereby, it will focus on Kenya Forest Service. The overall objective of this study was to investigate the factors influencing strategic information systems 
implementation in corporations in Kenya. This study was useful in the identification of critical factors for strategic ISs implementation which was important for consideration by heads of corporations when planning and designing the implementation project. This study was also helpful in giving suggestions that would help in improving the performance of parastatals in Kenya through the use of a successful IS. Finally, the study will be a source of reference material for future researchers on other related topics and would contribute to increasing knowledge in the field and add new scientific information in the area.

A survey conducted by information week, revealed that some of the significant reasons, for ISs project failures, considered by IT managers was lack of proper planning and management, change in business goals during the project and the lack of business management support. Langewalter cited in Umble et al., (2003) has claimed that, in between $40 \%$ to $60 \%$ of whole ISs implementation failed due to the above mentioned reasons. This highlights the importance of identifying the critical success factors to use to plan, carry out an evaluation of projects for successful implementation of ISs. Key Users like IT professionals are regarded by researchers such as Ifinedo (2007), Willcocks and Sykes (2000) and Markus and Tanis (2003) as being a great asset for modern organizations who are using IT systems in their operations. Willcocks and Sykes (2000) claims that IT professionals' technical backgrounds are very important both during the selection and acquisition of complex IT system like ERP and for the implementation of ERP system into adopting organizations. This view is also shared by Lee and Lee (2004); suggesting that IT professional's quality such as knowledge of the technological change and updated skills are important factors that are needed for ISs implementation success. However, Markus and Tanis (2003) suggest that IT professional's skills are also important at the postimplementation of IS as they provide support for end-users and the organization and making sure that the system runs smoothly.

In Kenya studies done on strategy implementation include Waema (2009), he studied the implementation of the financial management system in local authorities. Nyamboga and Gongera (2014) on the other hand did an evaluation of strategy implementation on organization effectiveness. Magutu and Lelei (2010) examined information systems implementation in state corporations, a critical evaluation of the process and challenges in Kenyan parastatals. However, no known study has been done to investigate factors influencing strategic IS implementation in Kenya Forest Service. The study seeks to fill in gaps in literature by assessing the factors that influence strategic ISs implementation in Kenyan parastatals, by producing a guideline that the parastatals can use to help define their needs and agendas with 
regard to ISs implementation and use and contributing to the body of knowledge on ISs implementation.

\section{Research methodology}

The research adopted a descriptive research design. Descriptive design is a method appropriate when collecting information about people's attitudes, opinions, habits or any of the variety of education or social issues (Orodho and Kombo, 2005). Descriptive research design according to (Kombo \& Tromp, 2006) enables the researcher provide description of phenomena or characteristics associated with the subject population without manipulation of variables. Further, Mugenda and Mugenda (2003) opined that the descriptive research collects data in order to answer questions concerning the current status of the subject under study. The main focus of this study was quantitative. However some qualitative approach were used in order to gain better understanding and possibly enable a better and more insightful interpretation of the results from the quantitative study. The study population consisted of staff working at the Kenya Forest Service in Mau Conservancy. The Head Mau Forest Conservancy - Nakuru has 8 ecosystems: Nakuru, Kericho, Narok, Bomet, Bureti, Koibatek, Transmara and Baringo. The populations for the study consisted of a total of 831 employees in different levels working directly with day to day information systems and were thus well conversant with the information sought by the study. Mugenda and Mugenda (2003), explain that the population should have some observable characteristics to which the researcher intends to generalize the results of the study. A sample population of 262 was selected using a formula suggested by Mugenda and Mugenda (2003) with confidence level and an error of 0.05 .

Data was collected by questionnaire while reliability was achieved by piloting the research questionnaires to a sample of 10 staff from KFS Nakuru. This pilot sample was however not included in the main sample for the actual study. According to Mugenda and Mugenda (2003) reliability is the consistency of a measure of the degree to which a research instrument yields consistent results or data after repeated trials. The instruments were then analyzed using the cronbach coefficient to determine the extent of reliability. A Cronbach Alpha reliability coefficient of 0.7 is adequate to declare the tools reliable based on (Cooper \& Schindler, 2008).

Multiple regression analysis is a statistical method utilized to determine the relationship between one dependent variable and one or more independent variables (Hair et al., 2010).

A summation of the scores of the regression analysis was then done.

$$
\mathrm{Y}=\beta 0+\beta 1 \mathrm{X} 1+\beta 2 \mathrm{X} 2+\beta 3 \mathrm{X} 3+\beta 4 \mathrm{X} 4+\varepsilon
$$


Whereby: $\mathbf{Y}=$ Strategic IS Implementation; $\mathbf{X 1}=$ Top management Support, $\mathbf{X} 2=$ Expertise , X3= End user training; $\mathbf{X} 4=$ infrastructure; B0, $\boldsymbol{\beta} 1$, $\boldsymbol{\beta 2}, \boldsymbol{\beta 3}, \boldsymbol{\beta 4}=$ Regression model coefficients. $\boldsymbol{\varepsilon}=$ Error Term.

\section{Results and discussions}

The study sought to determine whether top management support had an influence on strategic IS implementation. The findings revealed, top management resolve conflicts by mediating between groups had the highest level of mean 4.28 meaning that majority of the respondents concurred that the top management resolved conflicts by mediating groups. The standard deviation calculated from the analysis of .76507 indicated uniformity in the responses from the respondents. Also noted was that a great number of the respondents agreed top management ensures the best human, time and financial resources are chosen based on set policies and procedures. This was supported by the mean value calculated of 4.24. A significant number of the respondents also agreed to the statement; communication on IS changes is fully shared to the staff in all levels to build cooperation, this was established from the mean value calculated in the analysis of 4.16. The standard deviation of .83540 calculated in the SPSS indicated that most respondents were of a similar opinion. The Table 1 below shows the findings from the respondents.

Table 1: Influence of Top Management Support on Strategic IS Implementation

\begin{tabular}{lccccc}
\hline Statement & Min & Max & Mean & SDev \\
\hline $\begin{array}{l}\text { Top management ensures the best human } \\
\text {,time and financial resources are chosen based }\end{array}$ & 2.00 & 5.00 & 4.2400 & .76507 \\
$\begin{array}{l}\text { on set policies and procedures } \\
\begin{array}{l}\text { Top management decide on appropriate IS } \\
\text { and select suitable vendors }\end{array}\end{array}$ & & & & \\
$\begin{array}{l}\text { Top management resolve conflicts by } \\
\text { mediating between groups }\end{array}$ & 3.00 & 5.00 & 4.0400 & 4.00 & 1.11563 \\
$\begin{array}{l}\text { Communication on IS changes is fully shared } \\
\text { to the staff in all levels to build cooperation }\end{array}$ & 1.00 & 5.00 & 4.1600 & .63540 \\
$\mathrm{~N}=200$
\end{tabular}

The study also established that top management decide on appropriate IS and select suitable vendors. This was noted from the mean calculated of 4.04, which indicated that most respondents agreed to the statement and the standard deviation calculated of less than 1.5 indicates that there was little variance from the mean value. The findings of this study are in agreement with those of Nah et al. (2001) claiming that top managements are responsible for approving the ISs project and aligning it with the strategic goal of the business. Other top management responsibilities according to Nah et al. (2001) consists of allocating resources such as human, time and financial resources to the implementation effort. The results also confirm that 
although there are some variations in defining top managements duties in IS implementation, the importance of their commitment and support is highlighted by all referred researchers. Generally it was clear that top management support had a significant influence on strategic information system implementation.

Most respondents saw that expertise had a significant influence on strategic information system implementation at the Kenya Forest Service. It was established from the analysis that most respondents strongly agreed on the statement; IT professionals provide post implementation support to end users. This was established by the high mean value calculated of 4.45 . The standard deviation calculated of .666 indicates uniformity in the responses from the respondents. The findings are summarized in Table 2.

Table 2: Influence of Expertise on Strategic IS implementation

\begin{tabular}{|c|c|c|c|c|}
\hline Statement & Min & $\operatorname{Max}$ & Mean & SDev \\
\hline $\begin{array}{l}\text { There is enough human resource expertise to } \\
\text { participate in strategy implementation }\end{array}$ & 2.00 & 5.00 & 4.2400 & .76507 \\
\hline $\begin{array}{l}\text { There is a fit between the intended strategy } \\
\text { and the specific personality profile of the key } \\
\text { players in the different organizational } \\
\text { departments }\end{array}$ & 1.00 & 5.00 & 4.4400 & 1.11563 \\
\hline $\begin{array}{l}\text { IT professionals provide post implementation } \\
\text { support to end users }\end{array}$ & 3.00 & 5.00 & 4.4500 & .66620 \\
\hline $\begin{array}{l}\text { Employees have adequate access to the } \\
\text { organizations IT experts } \\
\mathrm{N}=200\end{array}$ & 1.00 & 5.00 & 4.0600 & .83540 \\
\hline
\end{tabular}

This study agreed with the findings of, Markus and Tanis (2003) who suggested that IT professional's skills are also important at the postimplementation of IS as they provide support for end-users and the organization and making sure that the system runs smoothly. From this analysis it was clear that the independent variable expertise had a significant influence on strategic information systems implementation.

The study also sought to establish the effect of infrastructure on strategic information systems implementation. From the analysis of the descriptive statistics, it was clear that most respondents believed that infrastructure had a significant influence on strategic information systems implementation. This was noted by the responses made from the respondents of statements related to infrastructure. For instance, it was noted there was necessary network and telecommunications technologies. This was seen by the high mean value calculated of 4.33. The standard deviation calculated of 0.666 indicated that majority of the respondents were of a similar opinion. It was also noted that respondents agreed that the management has installed the necessary computer hardware and software. This inference was established by the mean of 4.14. The small standard deviation of 1.11 indicated that there 
was little variance in the responses from the respondents. Also noted was that most respondents agreed that the organization has ensured that end users have adequate skills to use information systems. This was noted true by the mean calculated on the statement of 4.11. The standard deviation calculated in the study of 0.765 indicated uniformity in the responses from the respondents.

Table 3: Effect of infrastructure on Strategic IS implementation

\begin{tabular}{|c|c|c|c|}
\hline Statement & Max & Mean & SDev \\
\hline $\begin{array}{l}\text { The management has installed the necessary computer } \\
\text { hardware and software }\end{array}$ & 5.00 & 4.1400 & 1.11563 \\
\hline $\begin{array}{l}\text { There is necessary network and telecommunications } \\
\text { technologies }\end{array}$ & 5.00 & 4.3300 & .66620 \\
\hline $\begin{array}{l}\text { The IT professionals have adequate expertise to assist the } \\
1.00 \\
\text { end-users where necessary }\end{array}$ & 5.00 & 4.0200 & .83540 \\
\hline $\begin{array}{l}\text { The organization has ensured that end users have adequate }{ }_{2.00} \\
\text { skills to use information systems } \\
N=200\end{array}$ & 5.00 & 4.1100 & .76507 \\
\hline
\end{tabular}

Results also indicated that, all the staffs indicated that they needed training in IS for its successful implementation. Al-Mashari (2003) has underlined that end-users training should cover all aspects information systems. Francoise (2009) stressed for more user involvement throughout the IS implementation project, since end-users knowledge can be used in areas where the IS team lacks the expertise. Verville et al. (2006) showed that endusers involvement in acquisition phase of IS system results in end-users desire for technology purchase. The end-users desire for technology acquisition according to Verville et al. (2006) resulted in end-users open acceptance of the IS application following the implementation. It was noted from the analysis that end user training had a significant influence on strategic information systems implementation. This was noted true by the high mean values calculated on statements relating end user training and strategic information systems implementation.

Table 4: Effect of End user training on Strategic IS implementation

\begin{tabular}{|c|c|c|c|c|}
\hline Statement & Min & Max & Mean & SDev \\
\hline End users training equips user with required skills for success & 1.00 & 5.00 & 4.0400 & 1.11563 \\
\hline $\begin{array}{l}\text { End users should be involved before, during and after ISs } \\
\text { acquisition }\end{array}$ & 3.00 & 5.00 & 4.2800 & 66620 \\
\hline End users have the desire for Information Systems acquisition & 1.00 & 5.00 & 4.1600 & .83540 \\
\hline $\begin{array}{l}\text { End users considerations have been integrated into Information } \\
\text { systems strategy implementation } \\
N=200\end{array}$ & 3.00 & 5.00 & 4.2800 & 66620 \\
\hline
\end{tabular}

A regression analysis was done to establish the effect of independent variables (top management support, expertise, end-user training and infrastructure) on the dependent variable (strategic information systems implementation). 
These results are shown in the model summary below.

$$
Y=\beta_{0}+\beta_{1} \chi_{1}+\beta_{2} \chi_{2}+\beta_{3} \chi_{3}+\beta_{4} \chi_{4}+\varepsilon
$$

$\beta_{0}$ is the regression model constant; $\beta_{1}-\beta_{4}$ are the regression coefficients. $\mathrm{Y}$ is the employee performance depicted by the ratio of the amount subscribed/amount issued to the extent over subscribed. $\chi_{1}$ is the top management support, $\chi_{2}$ is expertise; $\chi_{3}$ is end user training; $\chi_{4}$ is infrastructure, and $\varepsilon$ is the error term obtained from the F-significance from Anova.

Table 5: Model Summaryc

\begin{tabular}{|l|l|l|l|l|l|}
\hline Model & $\mathrm{R}$ & R Square & $\begin{array}{l}\text { Adjusted } \\
\text { Square }\end{array}$ & $\begin{array}{l}\text { R } \\
\text { Std. Error of the } \\
\text { Estimate }\end{array}$ & Durbin-Watson \\
\hline 1 & $.933^{\mathrm{a}}$ & .870 & .833 & .00740 & $2.001^{\mathrm{b}}$ \\
\hline
\end{tabular}

a. Predictors: (Constant), top management support, expertise, end user training, Infrastructure

b. Dependent Variable: Strategic IS implementation

Table 5 presents the regression model summary to establish if regression analysis is suited for the data. The R-square tells the "goodness of fit" of the model. According to the regression analysis results, an R-square value of 0.870 was established depicting that the relationship of independent variables (top management support, expertise, end-user training and infrastructure) explain a strong $87 \%$ change in the dependent variable (strategic information systems implementation). The adjusted R2, also called the coefficient of multiple determinations, is the percent of the variance in the dependent explained uniquely or jointly by the independent variables. 83.3\% of the changes in strategic IS implementation in parastatals in Kenya could be attributed to the combined effect of the predictor variables. Pearson Correlation value of 0.933 was established depicting that the independent variables (Top management support, expertise, end-user training, infrastructure) had a very good linear relationship with the dependent variable (Strategic IS implementation). A Durbin Watson test for autocorrelation value of 2.001 was established depicting no (serial) autocorrelation within the regression model residuals. Thus, the random (non-stationary) data was used in the regression analysis.

Table 6: Analysis of Variance (Anova)

Anova $^{a}$

\begin{tabular}{|ll|l|l|l|l|l|}
\hline Model & & Sum of Squares & df & Mean Square & F & Sig. \\
\hline \multirow{4}{*}{1} & Regression & 138.880 & 3 & 46.293 & 120.869 & $.001 \mathrm{~b}^{\mathrm{b}}$ \\
& Residual & 75.272 & 196 & .383 & & \\
& Total & 214.152 & 199 & & & \\
\hline
\end{tabular}

a. Dependent Variable: Strategic IS implementation

b. Predictors: (Constant), top management support, expertise, end user training, infrastructure 
Anova analysis was conducted to determine the significance of the regression model. An F-significance value of 120.869 was established depicting that the regression model had very high significance. Also noted was that the regression model has a margin of error of $p<.001$. This indicates that the model has a probability of less than 0.1 of giving false prediction; this also points to the significance of the model.

Coefficients Table 7 below sought to identify which predictors are significant contributors to the $87.0 \%$ of explained variance in $\mathrm{Y}$ (i.e., $\mathrm{R} 2=.870$ ) and which ones are not. It also shows in what way the significant ones help to explain Y.

Table 7: Coefficients ${ }^{a}$

\begin{tabular}{|ll|l|l|l|l|l|}
\hline Model & \multicolumn{2}{|l|}{$\begin{array}{l}\text { Unstandardized } \\
\text { Coefficients }\end{array}$} & $\begin{array}{l}\text { Standardiz } \\
\text { ed Coef }\end{array}$ & T & Sig. \\
\cline { 3 - 5 } & & B & $\begin{array}{l}\text { Std. } \\
\text { Error }\end{array}$ & Beta & & \\
\hline \multirow{2}{*}{1} & (Constant) & .395 & .063 & & .697 & .594 \\
& Top management support & 1.938 & .001 & .989 & 2.957 & .023 \\
& Expertise & .874 & .003 & 1.246 & 3.234 & .014 \\
& Infrastructure & 1.485 & .002 & 1.466 & 2.784 & .028 \\
& End user training & .971 & .008 & .998 & 3.395 & .009 \\
\hline
\end{tabular}

a. Dependent Variable: Strategic IS implementation

The study established the following regression model:

Uptake $=.395+1.938 *$ Top management support $+0.874 *$ Expertise $+1.485 *$ Infrastructure $+0.971 *$ End user training

The first variable (constant) represents the constant also known as the Y-intercept, the height of the regression model when it crosses the $\mathrm{Y}$ axis. This is the predicted value of strategic IS implementation when top management support, expertise, end user training, infrastructure are zero, strategic IS implementation would be .395. The study also established that holding other factors constant, a unit increase in top management support would lead to a 1.938 increase in strategic IS implementation; a unit increase in expertise would yield a 0.874 increase in strategic IS implementation; a unit increase in infrastructure would result in a 1.485 increase in strategic IS implementation while a unit increase in end user training would yield to a .971 unit increase in strategic IS implementation. From the coefficients, it was established that each of the variables; top management support, expertise, end user training, infrastructure were significant in enhancing strategic IS implementation.

For the standard errors, these are the standard errors associated with the coefficients. For beta coefficients, these are the standardized coefficients. These are the coefficients that you would obtain if you 
standardized all of the variables in the regression, including the dependent and all of the independent variables, and ran the regression. By standardizing the variables before running the regression, you have put all of the variables on the same scale, and you can compare the magnitude of the coefficients to see which one has more of an effect. You will also notice that the larger betas are associated with the larger t-values and lower p-values. For each predictor variable in the equation, we are concerned with its associated standardized beta and t-test statistic's level of significance (Sig.). Whenever $\mathrm{p}<.05$, we find the results statistically significant. This means that when a p-value (SIG.) is less than or equal to .05, the corresponding beta is significant in the equation. From this equation, top management support $(\beta=.989, \quad p=.023<.05)$, expertise $(\beta=1.246, p=.014<.05)$, infrastructure $(\beta=1.466, p=.028<.05)$ and end user training $(\beta=.998, p=.009<.05)$ were statistically significant predictors

\section{Conclusion}

On effect of top management support on strategic implementation of information system, the study concluded that top managements role in the implementation of IS is highly important for the project as they ensure an even change management and system rollout. They are also responsible for setting the vision and business plan and to make sure to harness employees' creativity and energy. For IS implementation to be successful, strong commitment from upper management is essential since the introduction involves changing business practices and may require huge capital investments. Communicating the business vision and the role of IS system is also seen by Al-Mashari et al. (2003) to be a core responsibility of the top management in IS implementation process. It was also concluded that top management responsibilities which are in congruence with Nah et al. (2001) consists of allocating resources such as human, time and financial resources to the implementation effort.

On the influence of end-user training in the strategic implementation of information system, it was concluded that end-users should be involved in IS implementation and that training and education sessions on IS are very important (Al-Mashari, et al., 2003). Inappropriate or lack of training of endusers has been one of the main reasons behind many IS systems failure (Gupta, 2000). A case study that was conducted by Woo (2007) in order to find out the flaws of IS implementation projects that didn't succeed at the first attempt, highlighted end user training that was not given importance by a firm as a major flaw thus emphasizing on its importance.

On the influence of expertise on the strategic implementation of IS, it was concluded that IT professional's quality such as knowledge of the technological change and updated skills are important factors that are needed 
for an IS implementation success (Lee and Lee, 2004). Woo (2007) argues that IT professionals are mainly skilled in computer languages and technological aspect of information system rather than various aspects of the company's business operation.

On the establishment of the influence of infrastructure on the strategic implementation of IS, it was concluded that the results are congruent with those of McKay and Brockway (1989) who described IT infrastructure as the enabling foundation of shared IT capabilities upon which the entire business depends. This foundation is standardized and shared by business functions within the organization, and typically used by different organizational applications.

\section{Recommendations}

Based on the summary of the findings and the research objectives the study makes the following recommendations; on top management support, the study recommends that the organization should ensure that all the managers are computer literate and have attained computer packages plus professional packages. Further the study recommends that managers need to know how to implement IS in the organization for the purpose of successful operation of the parastatals in addition all managers and departments need to be directly involved in the use of IS systems in an organization. The study recommends that the top management at the Kenya Forest Service should remain fully committed throughout strategic IS implementation process. This will help to ensure clear and unbiased oversight of the implementations process ensuring time deadline are met within the stipulated time. This will ultimately increase the success of project implementation. The study further recommends that all managers and staffs should be trained on the use of IS before it is implemented in the organization. Training of users is important issue because if users will not be trained properly and understand the IS project's opportunities, they will resist the new system and reject using it.

On the establishment of the influence of infrastructure on the strategic implementation of IS, it is recommended that the organization should invest in the relevant technology for its successful implementation. Internal organizational structure also affects success of IS project. Therefore, there must be a high harmony between company's IS structure and infrastructure. The compatibility of company's structure and IS infrastructure is crucial milestone to implement an IS project otherwise project will fail dramatically. The IT capabilities of the firm should match to its organizational needs and goals. Organizational structural context of the company also affects the success of IS project for example traditional hierarchical organizations are poorly equipped to respond to new businesses. 
On the expertise on the strategic implementation of IS, the organization needs to enable the IT department to make periodic updates according to changes in users' needs and technology. This will clean up the bugs and make necessary updates. IT staff in the company must be trained about the new system and made capable of giving necessary help to the end users. In addition the study recommends that for an information system to be developed and be implemented successfully, it must fully align with the KFS organizational culture, structure and goals. Thus, initiatives and goals must be established within the organization to support and establish an organizational culture that embraces the organization's strategy over time that is the organizational culture must remain flexible.

\section{Suggestions for further studies}

The study recommends the following as areas of further research; ISs security issues in government parastatals and the challenges in ISs implementations in government parastatals. Also the same research could be replicated in other corporations and the results compared so as to establish whether there is consistency among the parastatals on the factors influencing strategic information systems implementation in corporations in Kenya.More research could also be conducted on the same organization this time including other stakeholders for example consultants,customers,suppliers and other key persons.

\section{References:}

Al-Mashari, M.,\& Zairi, M. (2003). Enterprise resource planning: taxonomy of critical factors. European Journal of Operational Research, Vol. 146 No.2, pp. 352-64.

Bekkers, V.,\&Zouridis S. (1999). Electronic Service Delivery in Public Administration: some trends and issues. International Review of Administrative Sciences, 65(2): 183-195.

Burke, R., Kenney.B., Kott .K, \&Pflueger.K. (2001).Success or Failure Human Factors in Implementing New Systems, Retrieved October 10th 2015.

Cooper, D., \&, Schind1er, P.S (2008). Business Research Methods. New Delhi, Tata McGraw Hill

Francoise, O. \& Pellerin, R. (2009). ERP implementation through critical success factors management. Business process management journal, Vol. 15 No.3, pp. 371-394.

Gupta, A. (2000). Enterprise resource planning: the emerging organizational value systems, Industrial Management \& Data Systems, April, 2000, Volume 100, Issue 3, p114-118. Hackney, R., Little, S. (1999) "Opportunistic 
strategy formulation for IS/IT planning", European Journal of Information Systems, Vol. 8 pp.119-26.

Infinedo, P., \& Nahar, N. (2009). Interactions between contingency, organizational IT factors, and ERP success. Industrial Management \& Data Systems, 109, 118-137.

Kombo, D. K., \& Tromp, D.L. (2006). Proposal and thesis writing: An introduction.Nairobi: Pauline’s Publications Africa.

Lee, A. S. (2003), "Re-introducing systems approach to Information Systems,” Key note address at Isone world Las Vegas,NV

Maguire, S. (2002). Identifying risks during Information System development: managing the process, Information Management \& Computer Security, August, 2002, Volume 10, Issue 3, p126- 134, Retrieved October $13^{\text {th }}$ 2015, from: http://www.emeraldinsight.com

Magutu, P., \&Lelei, J. (2010). "Information Systems implementation in State Corporations,” African Journal of Business \& Management,Vol. 1

Markus, M.L. and Tanis, C. (2003) "The enterprise system experience - from adoption to success”, in Zmud, R.W. (Ed.), Framing the Domains of IT Management: Projecting the Future Through the Past, Pinnaflex Educational Resources, Inc., Cincinnatti, OH, pp. 173-207.

McKay, D., \& Brockway, D.W. (1989). Building IT infrastructure for the 1990s. Stage by Stage 9(3), 1-11.

Miller, D. (2002). Successful change leaders: what makes them? What do they do that isdifferent?Journal of Change Management, 4,359-68.

Mugenda, O.,\& Mugenda,A.G. (2003).Research methods, qualitative and quantitative approaches. Nairobi: Acts Press African Center for Technology studies (ACTS)

Nah, F.H., Lau, L.S. \& Kuang, J., (2001). Critical factors for successful implementation of enterprise systems. Business Process Management Journal, Vol. 3 No.7, pp. 285-96.

Nyamboga T., \&Gongera E. (2014). “An evaluation of Strategy Implementation on Organization Effectiveness: Case of Kenya Wildlife Service, Garissa County,” European Journal of Business Management, Vol. 6, No16

Orodho, A.J. (2005). Techniques of writing Research Proposals and Reports. Masola Publishers Nairobi.

Turbit, N. (2005). ERP Implementation - The Traps, Retrieved Oct 11th 2015, from http:/www.projectperfect.com.au/info_erp_imp.php.

Verville, J.,\& Halingten, A. (2006). A qualitative study of the influencing factors on the decision process for acquiring ERP software, Qualitative Market Research: An International Journal,September, 2006, Volume 5, Issue 3, p188-198. 
Waema, T. M. (2009). Final Report for the Universal Access to Communication Services: Development of a Strategic Plan and Implementation Guidelines. Nairobi. Communications Commission of Kenya.

Willcocks LP and Sykes R (2000) The role of the CIO and IT function in ERP. Communications of the ACM 43

Woo, H.L (2007). Systematic planning for ICT intergration in topic learning.Educational Technology and society,10 (1),148-156 